\title{
Cooperative Learning (CL) in Promoting Oral Group Lessons
}

\author{
Wondwosen Tesfamichael Ali \\ Department of English Language \& Literature, Faculty of Social Science \& Humanities, Wolaita Sodo \\ University, Wolaita Sodo, Ethiopia \\ wondutesfa@gmail.com
}

\begin{abstract}
The purpose of this study was to assess whether or not the oral group lessons in the student English textbook of grade seven promoted CL. The study involved in the textbook, two English language teachers and one hundred twenty students who have been teaching and learning the English language, respectively at Muke Turi Primary and Junior Secondary School in Northern Shoa, Ethiopia. The data for the study were gathered through text analysis. In order to see the actual happening and to triangulate the findings of the text analysis, interviews were conducted and classrooms were observed. The results of the study showed that the oral group lessons in the textbook of grade seven fulfilled almost all the criteria of $C L$; the teachers and the students who were interviewed understood the benefits of sharing ideas through group work which in turn promotes CL though the number of the students in the class was large, and the students had poor background knowledge of English. The classroom observations proved that the number of students in the class was large; the desks were fixed; the students frequently used their mother tongue rather than English during group discussions; the teachers did not set a time limit for the discussions, and there were few practices of evaluating the oral group lessons after group discussions. The findings of this study indicate that the oral group lessons in the textbook helped to promote CL though there were problems to practice them in the classrooms.
\end{abstract}

Keywords : Cooperative Learning; Oral Group Lessons; Textbook Analysis

\section{Introduction}

Long and Porter (1985) argued that one of the main reasons for low achievement by many language learners is simply that they are not given the opportunity to practice the new language. Instead, their teacher sets the same instructional pace and content for everyone by lecturing, explaining a grammatical point, leading drill work or asking questions of the whole class. Since teacher-fronted lessons favor a highly conventionalized variety of conversation, one rarely found them outside classrooms and they may also limit the quality of talk students engage in.

It has been suggested that knowledge is constructed, discovered, transformed, and extended by students. If so, the main role of teachers is not to be dominant like what has been mentioned above but create conditions within which the students can construct meaning from what they are learning. This may, in turn, enable them to practice and refine their negotiation, organize and communicate skills, define issues and problems, and develop ways of solving them (Hopkins, 2002).

The conditions created by teachers will be realized if, among other things, students are put in groups. That is to say, group activities like role play, discussion; problem-solving, etc. could be used as means to make the learners actively involved in the learning process and internalize the language communicatively. In this regard, Chekering and Gamson (1987), as cited in Bonewell (2000), stated that learning is not a spectator sport. Students do not learn much just by sitting in class, listening to teachers, memorizing prepackaged assignments and spitting out answers. They must talk about what they are learning, write about it, relate it to past experiences, and apply it to their daily lives. They must make what they learn part of themselves. 


\subsection{Elements of $\mathbf{C L}$}

\section{Review of Literature}

In order for a lesson to be cooperative in the classroom, the five basic elements given below are included for long-term success.

a. Positive Interdependence

b. Face-To-Face Interaction

c. Individual Accountability

d. Social Skills

e. Group Processing

In general, the success of implementing the elements of CL in English as a foreign language classroom depends on the overall relationships among a teacher, learners and a textbook. To maximize this success, teachers should comprehend the various roles of a textbook and make their learners study it together and take something out of it on their own. In the section given below, let's see the roles of a textbook.

\subsection{Why Textbook Evaluation}

English language materials can be evaluated as they stand, without their roles in the classroom. However, this sort of evaluation does not help very much as it gives us no piece of information as to how the material works in the classroom (Breen, 1989). His ideas pave the ground for an evaluation of different aspects of the materials in process to get information about the ways in which students and teachers react to them.

Textbook evaluation can be very useful in teacher professional growth. It helps teachers acquire useful, accurate, systematic and contextual insights into the overall nature of textbook material. The evaluation of individual textbook and a complete instructional program is a key to the success of any instructional activity (Cunningsworth, 1995; Ellis, 1997). Thus, documentary study is one of the techniques to be carried out for the purpose of textbook evaluation. It deals with records that already exists (Sidhu, 1984).

In documentary study, the major emphasis is not with the general importance of the documents but with certain characteristics that can be identified and counted. Vocabulary analysis, textbook analysis, curriculum analysis, error analysis, report and job analysis are some examples of documentary study (Sidhu, 1984).Among the aforementioned examples of documentary study, textbook analysis is one of the common types of documentary study in the area of education in general and in language instruction in particular. As Sheldon (1987), stated that textbook analysis serves teachers to improve their skills and the instruction.

\section{Research Methods}

This study assessed whether or not the oral group lessons promote CL in the student's English textbook of grade seven.The subject of this study included English for Ethiopia Grade Seven in Northern Shoa, i.e. MukeTuri Primary and Junior Secondary School. The school was chosen on the basis of convenience to the researcher as there might not be significant differences among government primary and junior secondary schools concerning materials and methods they were using.

At Muke Turi Primary and Junior Secondary School, there were two teachers teaching grade seven English textbook. Both of them were selected for the study. These two teachers were teaching five sections. One of them covered four sections in which Oromo speaking students were found, and the other covered the remaining one section in which Amharic 
speaking students were being taught. Thus, from the three hundred and twenty-five students who were being taught in five sections, the researcher randomly selected two of the four sections of Oromospeaking classes which contained one hundred and forty students and also used the only Amharic speaking section which consisted of sixty-five students for classroom observations. In addition, among the two hundred and five students found in the three sections, six of them were selected for interview, i.e. randomly taking two students from each section as Sidhu (1984) explained that students are similar in many aspects, so a study on some of them will throw significant light upon the whole students.

\section{Discussion}

The data gathered from the textbook were analyzed andinterpreted; the studentswere interviewed, and classroom observations wereconducted. The results are presented below.

\subsection{Results of Grade Seven English Textbook Analyses andInterpretations}

The oral group lessons in the textbook were analyzed and interpreted based on the criteria suggested by Johnson and Johnson(1985). Having studied the textbook and itssyllabus, the following results were obtained and interpreted.

The textbook has sixteen units in which twenty-eight oral group lessons are found to be conducted in groups of four. Even though it is possible to use different size of groups, as Johnson and Johnson (1990), in Brubacher(1990: 123), say, "Cooperative groups tend to range in size from two to six", the researcher prefers to analyze the textbook with the oral group lessons done in groups of four to the oral group lessons done in pairs. This is because, the researcher believes that when students are in groups of four members, their CL situations during the oral group activities may be observed better than when they are in pairs. The oral group lessons in the text were assessed as per Johnson and Johnson's (1985)five criteria listed in the next section.

- Positive interdependence

- Face-to-face interaction

- Individual accountability

- Social skills

- Group processing

'Positive interdependence' criterion is about a structured lesson (task) that demands the teachers to divide the class into groups and require each group to complete the lesson with all members' participation for mutual benefits. This is to say that students should believe that they are linked with others in a way that one can't succeed unless the other members of the group succeed (and vice versa). In other words, students must perceive that they sink or swim together.

In this regard, from the twenty-eight oral group lessons, seventeen of them meet this criterion. For instance, in the ninth lesson of unit two, passage entitled as 'The Farmer and the Dishonest Person' is given. Before reading the passage, each member of the group discusses the difference between the work of a farmer and the work of a dishonest person using his/her experiences. Here, in order to make the group successful, the participation of each member is decisive. Having identified the possible differences that exist between them, each student reads the passage and then discusses the following five questions in small groups.

1. Why did the dishonest person say he lost two thousand birr? 
2. Why did the farmer reeturn home happily?

3. How do you think the dishonest person felt?

4. Do you think the farmer was honest ? Why?

5. What have you learnt from this story?

In order to learn something from the answers, learners need to work together, i.e. each learner ought to forward his/her own role while discussing the activity given above in groups.In the sixth lesson of unit ten, learners are asked to sort out the main idea of the story entitled as 'My Uncle, Yohannes: Champion for Others. In order to get more information, learners could summarize the story and discuss what they have done with one another. Here, each learner's contribution in the group is inevitable to challenge the given activity.

Table 1. Oral group lessons that show positive interdependence in grade 7 English textbook

\begin{tabular}{|c|c|c|c|c|c|}
\hline No & Criterion & $\begin{array}{c}\text { Total number of } \\
\text { oral group lessons } \\
\text { in the textbook }\end{array}$ & $\begin{array}{c}\text { Degree of } \\
\text { occurrence }\end{array}$ & $\begin{array}{c}\text { Number of oral } \\
\text { group lessons }\end{array}$ & Percent \\
\hline 1 & \multirow{2}{*}{$\begin{array}{c}\text { Positive } \\
\text { interdependence }\end{array}$} & 28 & Occur & 17 & 60.7 \\
\cline { 4 - 6 } & & & Partially occur & 11 & 39.3 \\
\cline { 3 - 6 } & & Absent & - & - \\
\cline { 3 - 6 } & & Total & 28 & 100 \\
\cline { 3 - 6 } & & & &
\end{tabular}

A 'Face-to-face interaction' criterion exists when students orally interact with one another in doing the given oral group lessons, discussing the ways and procedures of the oral group lessons with one another, and sharing ideas to learn from one another. Such face-toface interaction is promotive in the sense that students assist, encourage and support one another's efforts to learn the lessons. In this perspective, the oral group lessons in the student's textbook were assessed in line with the criterion given above.

The findings indicate that all the oral group lessons in one way or the other need faceto-face interactions to accomplish them. The oral group lessons in the textbook demand learners to work together. For instance, look at the following points raised in the textbook:

- Practice asking and answering personal information,

- Discuss the concept of hardworking and lazy student,

- Explain the responsibilities of each member's family using 'should',

- Talk about things that are seen in the environment,

- Express things using 'would' or 'wouldn't like',

- Talk with one another about their daily schedule of activities,

- Explain plans for the weekend to the partner and share rheir conversion with a small group

The summary of the oral group lessons in accordance with the criterion of the face-toface interaction is shown in the next table:

Table 2. Oral group lessons that promote face-to-face interactions in grade 7 English textbook

\begin{tabular}{|c|c|c|c|c|c|}
\hline No & Criterion & $\begin{array}{c}\text { Total number of } \\
\text { oral group lessons in } \\
\text { the textbook }\end{array}$ & $\begin{array}{c}\text { Degree of } \\
\text { occurrence }\end{array}$ & $\begin{array}{c}\text { Number of oral g } \\
\text { roup lessons }\end{array}$ & Per cent \\
\hline 2 & \multirow{2}{*}{$\begin{array}{c}\text { Promote face-to-face } \\
\text { interaction }\end{array}$} & 28 & Occur & 28 & 100 \\
\cline { 3 - 6 } & & Partially occur & - & - \\
\cline { 3 - 6 } & & Absent & - & - \\
\cline { 3 - 6 } & & Total & 28 & 100 \\
\hline
\end{tabular}

An 'Individual accountability' criterion refers to each member of the group who is accountable for contributing his/her share of the work to the group. Accordingly, the oral group lessons in the sixteen units were analyzed to see whether they foster individual 
accountability or not. In line with this, among the twenty-eight oral group lessons provided in the textbook, twenty-one of them meet this criterion. For example, in lesson one of the sixth unit, while working through the dialogue in groups to express their future wishes, needs and ambitions, each student practices expressing what he/she thinks.

Table 3. Oral group lessons that create individual accountability in grade 7 English textbook

\begin{tabular}{|c|c|c|c|c|c|}
\hline No & Criterion & $\begin{array}{c}\text { Total number of } \\
\text { oral group lessons in } \\
\text { the textbook }\end{array}$ & $\begin{array}{c}\text { Degree of } \\
\text { occurrence }\end{array}$ & $\begin{array}{c}\text { Number of oral } \\
\text { g roup lessons }\end{array}$ & Per cent \\
\hline 3 & $\begin{array}{c}\text { Create individual } \\
\text { accountability }\end{array}$ & 28 & Occur & 21 & 75 \\
\cline { 4 - 6 } & & Partially occur & 7 & 25 \\
\cline { 3 - 6 } & & Absent & - & - \\
\cline { 3 - 6 } & & Total & 28 & 100 \\
\hline
\end{tabular}

The contents of the oral group lessons are also assessed to see whether or not they can make learners practice some of the social skills like leadership, decision-making, trustbuilding, conflict management, etc. According to the study conducted on the twenty-eight oral group lessons in the student's textbook, fifteen of them meet a 'social skill' criterion. For instance, lesson four of unit six is about how learners can make use of 'would' to express their thoughts and wishes in conversation. This gives opportunities for learners to exercise how they are able to express their thoughts and wishes politely to others.

Table 4. Oral group lessons that cultivate social skills in grade 7English textbook

\begin{tabular}{|c|c|c|c|c|c|}
\hline No & Criterion & $\begin{array}{c}\text { Total number of } \\
\text { oral group lessons in } \\
\text { the textbook }\end{array}$ & $\begin{array}{c}\text { Degree of } \\
\text { occurrence }\end{array}$ & $\begin{array}{c}\text { Number of oral } \\
\text { group lessons }\end{array}$ & Per cent \\
\hline \multirow{2}{*}{4} & Cultivate social skill & 28 & Occur & 15 & 53.6 \\
\cline { 4 - 6 } & & & Partially occur & - & - \\
\cline { 4 - 6 } & & Absent & 13 & 46.4 \\
\cline { 3 - 6 } & & Total & 28 & 100 \\
\hline
\end{tabular}

One nature of cooperative group lessons in a textbook is having group processing which is used to explore the nature of the interaction processes that occurs within groups of learners. It may take five minutes or a whole lesson; it can happen immediately after the classroom interaction or on the next meeting. During the group processing, a teacher and students should be equally involved. Students must identify how well they have achieved their goals and maintained effective working relationships among members during the CL situations.

In this regard, among the twenty-eight oral group lessons in the textbook, one of them fulfill 'group processing' criterion. In lesson nine of the second unit, learners are ordered to talk about the difference between the 'work of a farmer' and the 'work of a dishonest person' in pairs. Having discussed the differences using their past experiences, they read the passage individually. Then each student with his/her partner answers the following questions orally:

1. Why did the dishonest person say he lost two thousand birr?

2. Why did the farmer return home happily?

3. How do you think the dishonest person felt happily?

4. Do you think the farmer was honest? Why?

5. What have you learned from this story?

After they have answered the comprehension questions mentioned above in groups, they groups take time to look into what they have done so far with their teacher. By doing so, learners may identify how well they have achieved their goals and maintained effective working relationship among themselves. 
Alongside with this, twelve of the twenty-eight oral group lessons partially fulfill this criterion. In these oral group lessons, the major concern is discussing the oral group lessons and reporting what learners have come up with in groups to the class. The instructions of the oral group lessons do not allow students to make use of some time to examine their working relationships and how well they have done so far towards the end of their works. For example, lesson one of unit five is about identifying certain things in the pictures given the textbook. With a partner, each learner talks about what he/she sees in each of the pictures. Then in groups of four, they discuss what they have seen in the pictures and report this to the class. Except report what they have identified to the class, the instructions do not make them take some time and evaluate the causes of the success or failure of their works as a group with a teacher. Thus, it is difficult for members of each group to make decisions about what behaviors to continue or change.

Table 5. Oral group lessons that enhance group processing in grade 7 English textbook

\begin{tabular}{|c|c|c|c|c|c|}
\hline No & Criterion & $\begin{array}{c}\text { Total number of } \\
\text { oral group lessons in } \\
\text { the textbook }\end{array}$ & $\begin{array}{c}\text { Degree of } \\
\text { occurrence }\end{array}$ & $\begin{array}{c}\text { Number of oral } \\
\text { g roup lessons }\end{array}$ & Per cent \\
\hline 5 & \multirow{2}{*}{$\begin{array}{c}\text { Enhance group } \\
\text { processing }\end{array}$} & 28 & Occur & 1 & 3.6 \\
\cline { 4 - 6 } & & Partially occur & 12 & 42.9 \\
\cline { 3 - 6 } & & Absent & 15 & 53.5 \\
\cline { 3 - 6 } & & Total & 28 & 100 \\
\hline
\end{tabular}

To sum up, the oral group lessons in the student's English textbook of grade seven have been analyzed and interpreted on the basis of the five criteria suggested by the scholars mentioned earlier.

\subsection{Results of the Students' Interview}

The researcher interviewed the students in Amharic in order to avoid the shortage of information because of English language difficulties, and the responses are summarized as follows.

"How often do you work in groups in the English language classes? How much emphasis do teachers and students give to it?" were the first questions raised. As to these questions, six of the interviewees replied that they worked in groups of four or five once a week. The rest respondents said that they frequently exercised oral group lessons. To the question how much emphasis the teachers and the students gave to the oral group lessons, all the interviewees agreed that almost all their teachers gave due attention to the oral group activities as they helped and monitored the learners while working in groups. However, five of the students said that there were some problems on the part of the students during the oral group activities. For instance, only a few members of the groups listened to what the teachers said in connection with the lessons being discussed. There were also some other students who sat idle because of their inabilities to make use of the language. In fact, this might emanate from their poor background knowledge of English.

The other question the students were asked was whether or not the oral group lessons in the textbook made them learn from one another while working together in groups. The responses of all the students were similar. They totally agreed that the oral group lessons in their textbook helped them learn from one another by sharing their thoughts.

The researcher asked the interviewees whether the oral group lessons in the text helped them practice the kind of social skills that they practiced through CL. In response to this question, thirteen of the interviewees confirmed that the oral group lessons in the text made them practice social skills listed below. 
Offering help one another. Persuading one another while discussing the activities_Expr essing thoughts freely without fear during $\mathrm{CL}_{-}$Exercising leadership_ Solving problems thro ugh discussions_Practice trust building_Exercising decision making

"After you have done the oral group lessons in the student's textbook, do you identify the causes of your failure or success, and discuss which behaviors continue or change? Why?" were the next questions raised to the interviewees. In response to these questions, eight of the fourteen respondents said that they sometimes evaluated what they had done so far in groups towards the end of their classes. By doing so, they were to practice being cooperative and correcting their mistake(s) which might cause them notto be effective in their oral group activities. However, two of the interviewees said that they rarely evaluated what they had done towards the end of their classes. On the other hand, four of the interviewees answered that they did oral group activities in groups of four or five once a week but their teachers didn't make them evaluate what they had exercised.

The other question the researcher raised was if the students had encountered with any problems while working together in groups, and if their answer is 'yes', they were asked to suggest some solutions that they thought in relation to the problems. In response to these questions, twelve of the interviewees said that there were some problems while working in groups. Some of the problems that they raised are listed as follows:

Finally, the researcher asked the students if they had additional remarks concerning the oral group lessons that may promote CL. As to this question, thirteen of the interviewees suggested that they wanted to the oral group lessons since:

They shared experiences while working together, help from partners increased both for the learners being helped as well as for those giving the help, i.e. for the students being helped, the assistance from their partners enabled them to move awayfrom dependence on teachers and gain more chances to enhance their learning. For the students offering help, the oral group lessons used as opportunities to increase their own performance, They were afraid of raising hands and expressed their thoughts before the class. However, when they were in groups, they were free to talk out what they had felt before their partners.

\subsection{Results of Classroom Observation}

The researcher observed grade seven classroom while they were being taught the oral group lessons. The observed oral group lessons were:

Tenses (Simple past and present perfect tenses)

The teacher, after revising what he taught yesterday for five minutes, he began the lesson by writing the example found on page 90 of the textbook on the blackboard as follows:

V1: I go to school every day.

V2: I went to school yesterday.

V3: I have gone to school for seven years.

Then he asked the class to identify the type of tenses in each sentence given in the example. Most of the students raised their hands and he randomly called the students by names and asked them to answer. They responded that the first one is simple present, the second is simple past and the last is present perfect tense. After this, he ordered them to write some other sentences of their own in groups of four or five or six as they were in their seats.

While he was trying to show as to how members of groups were writing sentences in relation to the tenses mentioned in the example, some other students in the other groups were sitting idle or discussing the activity in using their native languages. In fact, he was in a hurry to see what each group had tried to write. Nevertheless, a considerable number of groups 
were left without being offered help. As the number of the students was large, it was hard for him to work with each member of the groups.

After using up twenty-five minutes, he went in front and randomly called two students from different groups. He gave them two pieces of chalk and ordered them to write what their groups had agreed on the blackboard. After discussing the students' answers with the class, he corrected their answers on the blackboard. Without giving the chance to others to come in front, the period was over. Before he left the class, he ordered the students to do the second lessons of unit nine as homework.

\section{Conclusions}

Based on the findings, the following conclusions have been made. Though all the learners were equally beneficial from a CL, it was found that low achievers who were dependent on high achievers for their success benefit more from it without exertion. The students frequently used their native languages while discussing the oral group lessons and then translated their thoughts into English for presenting what they prepared for the class. After conducting CL, the students could not use of an effective way of evaluating the oral group activities to ameliorate future CL situations. The student's English textbook doesn't have rules, techniques and procedures which could be used along with the oral group lessons.

\section{References}

Ames, C. and Ames.R. (1985). Research on motivation in education. Orlando: Academic Press, Inc.

Bonewell, C.C. (2000). Active learning: Creating excitement in the classroom. Retrieved from: http://www.Active-learning-site.com

Breen, M. (1989). The evaluation cycle for language learning tasks. InR.K. Johnson (ed.). The second language curriculum. Cambridge: Cambridge University Press.

Christson, M. (1994). Cooperative learning in the EFL classroom. In T. Kral (ed.). Teacher development: Making the right moves. English Teaching Forum. 1989-1993. Washington English Language Program Divisions.

Cunningsworth, A. (1994). Evaluating and selecting EFL teaching materials. London: Heinemann Educational Books.

Ellis, R. (1997). The Empirical evaluation of language teaching materials. ELT Journal, 51/1:36-41.

Hopkins, D. (2002). Teacher's guide to classroom research (3rd ed.). United Kingdom: Open University Press.

Hutchinson, T. and Torres, E. (1994). The Textbook as agent of change. ELT Journal, 48/4:315-327.

Johnson, D.W.; Johnson, R.T., and Holubec, E.J. (1993). Cooperative learning. Retrieved from http://www.co.operation.org/pages/c/.htm/

Johnson, D.W. and Johnson, R. T. (1985). The international dynamics of learning groups. In R. Slavin, et. al (eds.). Learning to cooperate, cooperating to learn. New York: Plenum Press.

Long, M.H. and Porter, P.A. (1985).Group work, Inter language talk, and second language acquisition. TESOL Quarterly, 19/2:207-210.

Ur, P. (1996). A Course in Language Teaching. Cambridge: Cambridge University Press.

Wenden, A. (1991). Learner strategies for learner autonomy. Englewood Cliffs. NJ: Prentice Hall.

Williams, M. and Burden, R. (1997). Psychology for language teachers: A social constructivist approach. Cambridge: Cambridge University Press. 